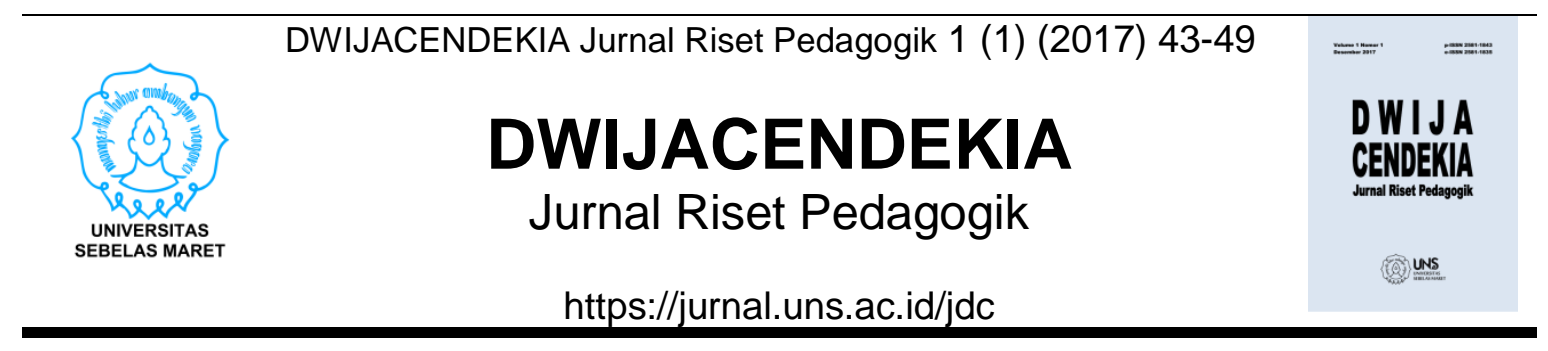

\title{
PENGGUNAAN METODE KARYAWISATA UNTUK MENINGKATKAN HASIL BELAJAR SISWA PADA MATERI KENAMPAKAN ALAM DI LINGKUNGAN KABUPATEN/KOTA
}

\section{Euis Dartini}

SDN 1 Nagarasari Kota Tasikmalaya

\section{Sejarah Artikel}

Diterima 22 Juli 2017

Disetujui 27 Juli 2017

Diterbitkan 1 Agustus 2017

Kata Kunci

Metode Karyawisata, Hasil

Belajar, Kenampakan alam

\begin{abstract}
Abstrak
Hasil belajar siswa kelas IV SDN 1 Nagarasari pada pembelajaran Ilmu Pengetahuan Sosial masih rendah. Terlihat dari hasil evaluasi yang telah dilaksanakan, hanya $21 \%$ siswa yang mencapai batas minimal kecapaian kompetensi. Tingkat kejenuhan siswa terhadap pelajaran IPS sangatlah tinggi. Hal tersebut terjadi karena proses pembelajaran yang hanya menggunakan metode ceramah. Penggunaan metode karyawisata ini bertujuan untuk mendeskripsikan hasil belajar sebelum dan setelah menggunakan metode pembelajaran karyawisata. Penelitian tindakan kelas ini dilaksanakan dengan subyek penelitian siswa kelas IV SDN 1 Nagarasari Tahun Pelajaran 2015/2016 sebanyak 28 orang. Pengambilan data dilakukan dengan menggunakan metode tes dan non test. Dimana dilakukan observasi dan dokumentasi.hasil penelitian menunjukan perubahan hasil belajar yang significant sebelum dan setelah pembelajaran. Dimana pada siklus pertama menunjukan $57 \%$ siswa mengalami peningkatan hasil belajar. Dan pada siklus kedua menunjukan $82 \%$ siswa telah menyelesaikan batas KKM
\end{abstract}

\section{Cara Mengutip}

Dartini, E. (2017). Peggunaan Metode Karyawisata Untuk Meningkatkan Hasil Belajar Siswa pada Materi Kenampakan Alam di Lingkungan Kabupaten/ Kota. DWIJACENDEKIA Jurnal Riset Pedagogik, 1(1), 43-49.
Korespondensi Penulis:

euis.dartini.naga1@gmail.com
p-ISSN 2581-1843

e-ISSN 2581-1835 


\section{PENDAHULUAN}

IImu Pengetahuan Sosial merupakan salah satu pelajaran yang harus diterima oleh siswa sekolah dasar. Sesuai dengan peraturan pemerintah nomor 19 tahun 2005 salah satu kelompok mata pelajaran adalah ilmu pengetahuan dan teknologi. Kelompok mata pelajaran ilmu pengetahuan dan teknologi pada jenjang pendidikan dasar dilaksanakan salah satunya melalui muatan dan atau kegiatan ilmu pengetahuan sosial.

Salah satu materi yang harus disampaikan pada mata pelajaran IImu Pengetahuan Sosial kelas IV adalah kenampakan alam di lingkungan Kabupaten/Kota. Pada materi tersebut siswa dituntut untuk dapat mendeskripsikan kenampakan alam dengan keragaman sosial dan budaya di lingkungan sekitarnya.

Permasalahan yang muncul pada pembelajaran IPS di dalam kelas adalah rendahnya hasil belajar siswa. Berdasarkan hasil studi pendahuluan, rendahnya hasil belajar siswa terjadi karena beberapa alasan. Hal pertama yang menjadi alasan adalah ketidaksukaan siswa terhadapa pelajaran IPS yang berupa hapalanhapalan. selain itu, tingkat kejenuhan siswa yang dikarenakan cara mengajar guru yang hanya menggunakan metode ceramah dalam menyampaikan materi IPS.

Metode ceramah yang dilakukan oleh guru karena beberapa alasan. Metode ceramah adalah metode yang paling murah yang hanya mengandalkan kemampuan berbicara. Selain itu, ketidaktahuan guru terhadap variasi metode pembelajaran mempengaruhi guru dalam memilih metode belajar di kelas. Padahal menurut Abu (2005:53) mengatakan "metode pembelajaran untuk menyampaikan materi IPS diantaranya (1) ceramah, (2) metode tanya jawab (3) diskusi, (4) pemberian tugas, (5) demonstrasi, (6) sosiodrama (7) simulasi eksperimen, (9) karyawisata".

Semua metode tersebut diatas bagus jika digunakan dengan materi yang sesuai. Seperti halnya metode karya wisata akan cocok ketika materi yang terkait dengan lingkungan. Karena metode karyawisata adalah cara mengajar yang yang dilaksanakan dengan mengajak seluruh siswa ke luar kelas mengunjungi satu lokasi/objek nyata. Metode ini menyajikan kondisi nyata sehingga siswa mendapatkan pengalaman/pengetahuan langsung bukan hanya sebatas pengetahuan verbal berdasarkan informasi saja (Kartawidjaja, 1987 : 15).

Metode ini menempatkan guru sebagai fasilitator. Tugas guru menyiapkan lembar kerja yang harus diisi oleh siswa ketika berada dilokasi pembelajaran. Guru menyiapkan langkah-langkah dalam lembar kerja tersebut agar siswa dapat mencapai tujuan pembelajarannya.

Sementara itu, SD Negeri 1 Nagarasari merupakan salah satu sekolah yang berada di wilayah Dinas Pendidikan Kota Tasikmalaya. Kota Tasikmalaya adalah sebuah kota kecil yang berada di wilayah provinsi Jawa Barat. Kota Tasikmalaya adalah kota yang dikelilingi oleh gunung-gung yang cukup tinggi dan sungai yang mengalir yang bersumber dari gunung tersebut. Selain itu, Kota Tasikmalaya juga memiliki danau buatan yang cukup luas.

Dari latar belakang tersebut, penulis memiliki ketertarikan untuk meneliti apakah dengan memanfaatkan kenampakan alam yang berada di 
wilayah Kota Tasikmalaya dapat meningkatkan hasil belajar siswa. Penelitian ini diberikan judul "Penggunaan Metode Karyawisata untuk Meningkatkan Hasil Belajar Siswa Pada Materi Kenampakan Alam di Lingkungan Kabupaten/Kota".

Adapun tujuan dari penelitian ini adalah 1) untuk mendeskripsikan pembelajaran dengan menggunakan metode karyawisata pada materi kenampakan alam di lingkungan Kabupaten/Kota, 2) mendeskripsikan hasil belajar yang diperoleh setelah menguunakan metode karyawisata pada materi kenampakan alam di lingkungan Kabupaten/Kota.

\section{METODE PENELITIAN}

Metode yang digunakan adalah Metode Penelitian tindakan Kelas (action research).

Tempat pelaksanaan penelitian adalah SDN 1 Nagarasari Kecamatan Cipedes Kota Tasikmalaya. SDN 1 Nagarasari memiliki 3 kelas paralel setiap jenjang. Subjek penelitian adalah Siswa Kelas IV A. yang berjumlah 28 orang. Siswa tersebut terdiri dari 17 siswa perempuan dan 11 siswa laki-laki.

Prosedur penelitian tindakan kelas ini menggunakan modell Kemmis dan Mc Taggrat. Model tersebut merupakan pengembanagan dari model yang diperkenalkan oleh Kurt Lewin yang kemudian dimodifikasi pada tahap tindakan (acting).

Setiap siklus berdasarkan prosedur tersebut bermula dari perencanaan, tindakan dan pengamatan, serta diakhiri refleksi siklus. Pada tahapan refleksi dintetukan apakah akan dilaksanakan tindakan berikutnya atau dinyatakan penelitian telah berhasil sesuai dengan kriteria keberhasilan yang telah ditentukan. Selain itu, refleksi yang dilakukan menyangkut analisis, sintesi dan penilaian hasil tindakan yang telah dilakukan.

Refleksi tersebut dilakukan secara bersama-sama dengan observer. Permasalahan yang muncul ketika proses belajar dapat disampaikan oleh observer yang kemudian didiskusikan untuk mencari solusi pada siklus berikutnya. Selain itu, ide dan gagasan baru.

Subjek penelitian ini adalah siswa kelas IV A SD Negeri 1 Nagarasari. Siswa kelas IV A berjumlah 28 orang. Siswa perempuan berjumlah 16 orang dan siswa laki-laki berjumlah 12 . Siswa kelas IV dibagi menjadi 7 kelompok. Kelompok dibagi berdasarkan kemampuan akademis siswa.

\section{PEMBAHASAN}

\section{Hasil Pra siklus}

Pra siklus adalah studi pendahuluan yang dilakukan sebelum menggunakan metode karyawisata. Tujuan dari prasiklus adalah untuk mengetahui kemampuan awal siswa dalam menjawab pertanyaanpertanyaan yang berhubungan dengan kenampakan alam yang sudah disampaikan oleh guru dengan menggunakan metode ceramah. Pra siklus dilakukan dengan melihat hasil belajar siswa khususnya pelajaran ilmu pengetahuan sosial pada materimateri sebelumnya. 
Adapun hasil pra siklus yang diperoleh oleh siswa kelas IV A adalah nilai tertinggi yang diperoleh oleh siswa adalah 82,5 dan nilai yang terendah adalah 40 . Dengan rata-rata hasil belajar sebesar 66.25.

Temuan yang diperoleh sebelum siklus adalah kekurang metode pembelajaran yang digunakan oleh guru sehingga siswa merasa jenuh untuk menghadapi pelajaran IPS. Penulis dan observer berpendapat perlunya sebuah perbaikan pembelajaran sehingga dapat meningkatkan hasil belajar siswa kelas IV A. untuk meningkatkan hasil belajar siswa akan dilaksanakan tindakan pada siklus I dengan menggunakan variasi metode pembelajaran. Jika pada awalnya hanya menggunakan metode ceramah, pada pertemuan di Siklus I akan menggunakan metode karyawisata. Selain itu, pemberian kesempatan siswa untuk terlibat langsung dalam proses pembelajaran, menyampaikan pendapat dirasakan akan meningkatkan hasil belajar.

\section{Hasil Test Siklus 1}

Siklus I dilaksanakan pada hari Hari Jum'at tanggal 28 Agustus 2015 dan sabtu 5 September 2015. Pada pertemuan awal siswa dan guru berdiskusi untuk karyawisata di lokasi pertama. Guru dan siswa mendiskusikan lokasi pertama yang akan dikunjungi yaitu tempat wisata Situ Gede. Guru dan siswa mengadakan kontrak sosial aturan sebelum berangkat, ketika di lokasi, dan pulang dari lokasi.

Hasil belajar yang diperoleh oleh siswa pada siklus I ini dalam materi kenampakan alam di lingkungan kabupaten/kota Kelas IV SD Negeri 1 Nagarasari diketahui nilai tertinggi yang diraih siswa adalah 90, sementara nilai terendah yang diperoleh oleh siswa adalah 55 dengan rerata hasil belajar adalah 72.41 .

Hasil penelitian pada siklus I menunjukan peningkatan nilai rerata dari hasil belajar siswa kelas IV SDN 1 Nagarasari. Pada pra siklus rerata siswa kelas IV adalah 66.25. Sementara setelah dilakukan pembelajaran dengan metode karyawisata mendapatkan rerata nilau sebesar 72.41. meningkat 6.16 point dari keadaan pra siklus. Perbandingan perolehan hasil belajar siswa sebelum dan sesudah tindakan dan akhir siklus I dapat disajikan seperti tertera pada gambar 1.

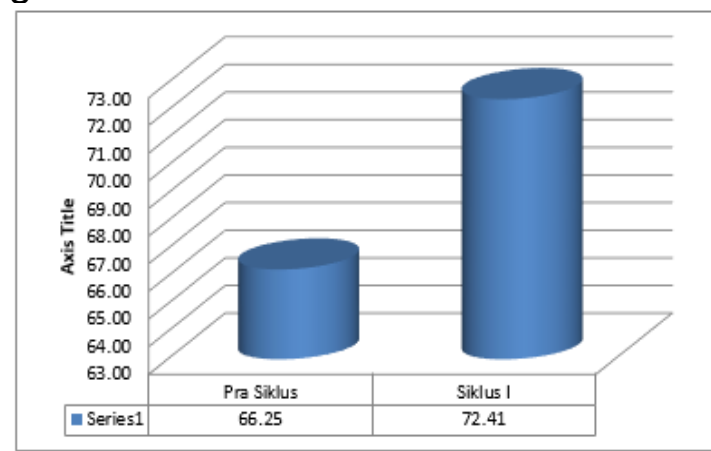

\section{Gambar 1. Perbandingan nilai pra siklus dengan siklus I}

Berdasarkan data tersebut pada siklus I menunjukan bahwa hasil belajar siswa secara individual sudah ada peningkatan. Walaupun hasilnya belum terlalu significant dari pra siklus. Tetapi jumlah siswa yang mencapai nilai KKM telah mencapai lebih dari $50 \%$.

Pada siklus pertama berdasarkan hasil refleksi dengan observer terdapat beberapa kekurangan/ kendala pada siklus pertama. Kendala yang terjadi adalah siswa yang senang ketika sampai ke tempat tujuan sementara melupakan tujuan dari karyawisata tersebut. Kendala lain adalah kurangnya tenaga 
pendidik untuk menjadi fasilitator selama kegiatan berlangsung. Mengingat lokasi yang begitu besar sehingga siswa kurang terperhatikan. Oleh karena itu, perbaikan pembelajaran diharapkan pada sikus II nanti. Sementara itu, dalam tahap perencanaan ada hal yang harus diperbaiki. Diantaranya, perbaikan lembar kerja yang lebih baik untuk memandu berjalannya pembelajaran dengan metode karyawisata tersebut.

\section{Hasil Test Siklus 2}

Berdasarkan hasil refleksi pada siklus pertama, penulis mencoba memperbaiki kekurangan-kekurangan yang terjadi pada siklus pertama. Penulis memperbaiki perencanaan dengan menyiapkan lembar kerja yang lebih sistematis dan keterbacaan siswa. Dengan perbaikan tersebut diharapkan siswa menjadi lebih terarah dalam mengerjakan lembar kerja siswa.

Siklus II dilaksanakan pada hari Jum'at dan sabtu pada tanggal 11-12 September $2015 . \quad$ Setelah mendiskusikan antara guru dengan siswa maka sepakat lokasi yang akan di kunjungi adalah kawah Gunung Galunggung.

Hasil belajar siswa kelas IV A SD Negeri 1 Nagarasari pada siklus II tentang kenampakan alam di lingkungan kabupaten/kota dengan menggunakan metode karyawisata mengalami peningkatan yang cukup signifikan. Dari 28 orang siswa kelas IV sebanyak 26 orang siswa mencapai batas kriterian ketuntasan minimal. Dengan perolehan nilai tertinggi yaitu 95 dan nilai yang paling rendah 60 , dengan rerata hasil belajar 80,14 .

Dari hasil belajar tersebut menunjukkan bahwa rerata hasil belajar siswa pada siklus I dan siklus
II mengalami perubahan yang cukup signifikan. Dimana pada siklus I mendapatkan rerata 72.41 dan siklus II sebesar 80,14. Itu artinya siklus II lebih tinggi sebedar 7.67 dibandingkan siklus II. Perbandingan perolehan hasil belajar siswa pada akhir siklus II untuk masing-masing siklus dapat disajikan seperti pada gambar 2.

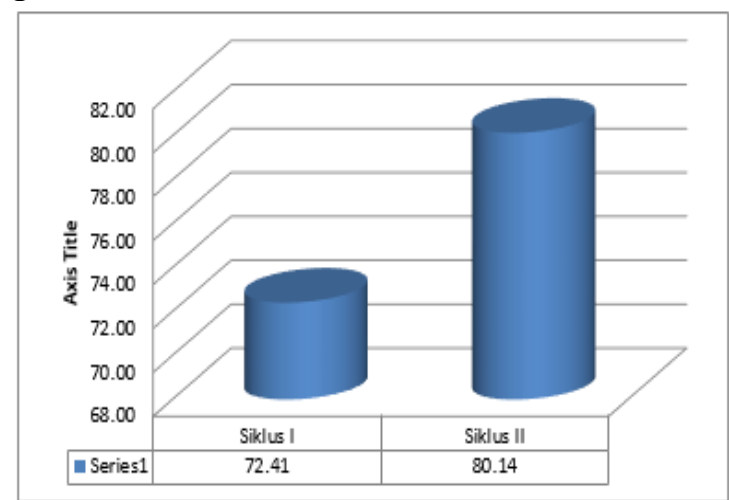

\section{Gambar 2. Perbandingan nilai Siklus I dan Siklus II}

Pada gambar 2 tersebut diatas dapat dilihat bahwa rerata hasil belajar pada siklus II mengalami peningkatan dari siklus I. pada siklus I rerata siswa mencapai 72.41 dan panda siklus II meningkat menjadi 80.14. dari 28 orang siswa kelas IV A yang telah mencapai KKM sebanyak 26 Orang. Itu artinya 92\% Kelas IV A telah mencapai KKM. Sementara itu, kriteria keberhasilan penelitian ini pada pelajaran IPS adalah sebesar 75 dan $75 \%$ dari seluruh siswa melampaui KKM.

Dengan demikian, berdasarkan hasil belajar siswa kelas IV A pada materi kenampakan alam dengan menggunakan metode karyawisata dapat disimpulkan dapat meningkatkan hasil belajar siswa. Hal tersebut disimpulkan karena dengan perbaikan proses pembelajaran pada tahap pra siklus, siklus I dan siklus II dapat terlihat adanya peningkata 
proses pembelajaran dan hasil belajar.

Adapun kendala-kendala yang ditemui pada tahapan pra siklus, siklus I telah terselesaikan pada siklus II. Seperti halnya kekonudisfan siswa selama kunjungan dapat diatasi dengan kontrak sosial yang dibuat sebelumnya. Selain itu, kekurangan personil / fasilitator dapat diatasi pada siklus II dengan menambah personil.

Menurut Sudarsono (1992:58-63) untuk meningkatkan hasil belajar siswa perlu ditingkatkan keinginan/minat anak terlebih dahulu. Dalam meningkatkan minat tersebut maka diperlukan beberapa hal yang diantaranya : 1) belajar harus dapat menarik perhatian anak, 2) Objek atau sistuasi pembelajaran yang memikat siswa, 3) masalah kesharian siswa yang berulang-ulang dapat mendorong keingintahuan siswa, 4) kegiatan pembelajarana semua harus diluar dari kebiasaan tetapi tidak terlepas daro tujuan yang telah ditentukan, alat/instrumen harus tersedia, dan metode pengajaran yang tepat.

Dari pemaparan tersebut, sesuai dengan penelitian yang telah dilakukan maka dirasakan tepat menggunakan metode karyawisata. Penggunaan metode tersebut berdasarkan pembelajaran yang selama ini dilakukan. Adanya kejenuhan siswa dalam pembelajaran yang hanya begitu-begitu saja yang hanya menggunakan metode ceramah.

Metode karyawisata itu sendiri menurut sagala (2003:214) adalah pesiar yang dilakukan oleh peserta didik di luar kelas. Kegiatan tersebut dilaksanakan untuk melengkapi pengetahuan yang telah diperoleh siswa setelah mendapatkan pengalaman belajar yang telah tercantum di dalam kurikulum yang telah ditetapkan. Oleh karena itu, sejalan dengan pandangan bahwa untuk meningkatkan minat belajar siswa penulis merasa sangat tepat dengan menggunakan metode karyawisata.

Hal tersebut dapat terlihat dari hasil belajar yang di tunjukan oleh siswa ketika prasiklus, siklus I, dan siklus II sangat menunjukan peningkatan yang signifikan. Rerata hasil belajar siswa ketika prasiklus yaitu 66,25 meningkat pada siklus I menjadi 72,41. Yang lebih menunjukan peningkatan yang lebih pesat pada siklus ke II yaitu 80,14 . Jika dilihat dari jumlah siswa yang mencapai KKM dari 28 siswa, sebanyak 26 orang siswa sudah mencapai KKM. Atau sebanyak $\pm 92 \%$ siswa mencapai kriteria keberhasilan pembelajaran.

Selama penelitian berlangsung, terdapat beberapa kendala yang harus dipecahkan oleh peneliti. Pada siklus I banyak siswa yang mengalami kesulitan dalam membaca langkahlangkah pengerjaan lembar kerja siswa. Selain itu, sikap alamiah anak ketika berada di lingkungan yang baru akan lebih tertarik untuk mencari tahu. Hal tersebut menyebabkan siswa tidak fokus kepada tujuan pembelajaran dan lebih senang untuk main. Keterbatasan fasilitatorpun menjadi kendala yang cukup berat. Karena dengan jumlah peserta didik sebanyak 28 hanya ada 2 orang guru yaitu peneliti dan observer.

Oleh karena itu, semua kendala tersebut harus diatasi dalam pembelajaran pada siklus berikutnya. Karena inti dari penelitian tindakan kelas adalah perbaikan proses pembelajaran yang dialami oleh guru di dalam kelas. Perbaikan proses 
pembelajaran tersebut diharapkan meningkatkan hasil belajar.

\section{SIMPULAN}

Berdasarkan hasil penelitian yang telah dilaksanakan tentang pembelajaran IPS pada materi kenampakan alam di lingkungan kabupaten/kota dengan menggunakan metode karyawisata dapat disimpulkan: 1) pembelajaran IPS bukanlah pembelajaran yang memfokuskan kemampuan menghafal saja, tetapi kemampuan lainpun dapat diasah. Pembelajaran pun tidak hanya metode ceramah saja, melainkan masih ada metode-metode lain yang tepat digunakan pada materi pelajaran IPS. Salah satunnya metode karyawisata yang mebuat anak-anak senang. Karena anak dibawa ke suatu tempat untuk melengkapi pengetahuan yang telah mereka dapatkan di dalam kelas. 2) hasil belaajr siswa pada materi kenampakan alam di lingkungan kabupaten/kota dengan menggunakan metode ceramah mengalami peningkatan yang signifikan. Mulai dari prasiklus hingga siklus II. Rerata hasil belajar siswa ketika prasiklus yaitu 66,25 meningkat pada siklus I menjadi 72,41. Yang lebih menunjukan peningkatan yang lebih pesat pada siklus ke II yaitu 80,14.

Berdasarkan hasil penelitian yang dilaksanakan kepada siswa kelas IVA SDN 1 Nagarasari, peneliti mengajukan saran yang ditunjukan kepada guru dan sekolah. Untuk guru disarankan pembelajaran IPS agar dikemas lebih menarik. Karena di kehidupan nyata bukan hanya permasalahan matematika dan IPA saja tetapi pembelajaran IPS pun dapat bermanfaat untuk kehidupan sehari-hari. Jika anak ketika belajar IPS sudah tidak berminat karena hanya menggunakan metode yang ituitu saja, ditakutkan siswa tidak memiliki kecakapan sosial yang digunakan di masyarakat.

Selain itu, untuk sekolah peneliti mengajukan saran agar dapat memfasilitasi proses pembelajaran dengan menggunakan metode karyawisata. Karena metode ini memerlukan dana yang cukup besar terutama dalam transportasi. Oleh karena itu, diharapkan dana transportasi pembelajaran ini dapat dituangkan dalam RKAS

\section{DAFTAR PUSTAKA}

Arikunto, Suhardjono dan Supardi. (2008). Penelitian Tindakan Kelas. Jakarta: Bumi Aksara.

Permendiknas. (2005). Peraturan Pemerintah Nomor 19 Tahun 2005 tentang Standar Nasional Pendidikan. Jakarta: Depdiknas
Sagala, Saiful. (2003). Konsep dan Makna Pembelajaran. Bandung: Alfabeta

Soewardi Kartawidjaja, Eddy. (1987). Pengukuran dan Hasil Evaluasi Belajar. SINAR BARU: Bandung 